\title{
INFLUENCE OF AN IUD ON THE LEUCOCYTIC CONTENT OF THE UTERUS AND ON THE DURATION OF PSEUDOPREGNANCY IN MICE
}

\author{
A. BARTKE \\ Worcester Foundation for Experimental Biology, \\ Shrewesbury, Massachusetts, U.S.A. \\ (Received 30th October 1969, revised 26th Fanuary 1970)
}

\begin{abstract}
Summary. Female mice had unilateral, silk thread IUDs removed 1, 2, 3 or 4 days after mating and were killed 1 to 5 days later. Histological sections of both uterine horns, or the uterine contents flushed out with water, were examined for the presence of leucocytes. Polymorphonuclear leucocytes which are invariably present in the lumen and endometrium of all horns containing an IUD and in a proportion of contralateral untreated horns, had usually disappeared in less than $48 \mathrm{hr}$ after removing the IUD. This may explain the occurrence of implantations in mice from which the IUDs were removed 1 to 3 days after mating.

The duration of pseudopregnancy in mice with IUDs was increased and was more variable than in untreated mice.
\end{abstract}

\section{INTRODUGTION}

A silk thread placed in one uterine horn of the laboratory mouse prevents implantation in that horn and inhibits both implantation and embryo survival in the contralateral untreated horn (Doyle \& Margolis, 1966; Bartke, 1968). Marston \& Kelly (1969) reported that the unilaterally placed IUD caused extensive leucocytic infiltration in both horns and suggested that this might be responsible for its bilateral contraceptive effect. A direct toxic effect of leucocytic extracts on the early embryo was recently demonstrated in the rat (Parr, 1969a). Since implantation can occur in female mice from which an IUD was removed as late as the 3rd day after mating (Bartke, 1968), it was decided to study the rate of disappearance of leucocytes from the uterus after IUD removal.

In addition, IUDs have been reported to cause luteolysis in several species (review in Parr, 1969b). To test whether an IUD shortens the life-span of corpora lutea in laboratory mice, the duration of pseudo-pregnancy was compared in intact and in IUD-bearing females.

\section{MATERIALS AND METHODS}

All mice were of the Charles River Co. CD-I random-bred strain and approxi- 
mately 2 months old at the beginning of experiments. The method of inserting and removing the IUDs has already been described (Bartke, 1968).

\section{Experiment 1}

Twenty-four mice were given unilateral IUDs and five were left untreated. The animals were placed with adult males 20 days later and checked daily for the presence of vaginal plugs. In sixteen mice, IUDs were removed on the lst, 2nd, 3rd or 4th day of pregnancy, while in the remaining eight mice, they were left in situ. All animals were killed on the 6th day. At autopsy the uteri were examined for the number of implantations, dissected out and flushed with 0.1 to $0.2 \mathrm{ml}$ of tap water using a syringe with a blunt 20-gauge needle. The needle was inserted into one end of the uterine horn which was held firmly with forceps around the needle while water was forced through the lumen. The flushings were collected on a microscope slide from the other end of the horn and examined immediately for the presence of leucocytes.

\section{Experiment 2}

Twenty-one mice received unilateral IUDs and seven served as controls. These mice were placed with males 12 or 20 days later. In thirteen females, IUDs were removed 1 day after the plug was found and the animals were killed 1, 2, 3 or 4 days later (i.e. on the 3 rd, 4 th, 5 th or 6 th day of pregnancy), three or four animals on each day. Intact mice and the eight mice with an IUD left in situ were killed at the same intervals after mating. The uterine horns were fixed in Bouin's solution, sectioned in Paraplast at $7 \mu$ and stained with haematoxylin and eosin. A number of sections from different parts of each horn, including the part containing an IUD, was examined for the presence of leucocytes.

\section{Experiment 3}

Eight mice were given unilateral IUDs, eight bilateral IUDs, seven were intact and six were hysterectomized. In these six animals, both uterine horns were excised after tying the uterine branches of the ovarian arteries and veins at the level of the oviducts and at the level of the cervix and placing a tight suture around the cervix. All the females were placed with vasectomized males 9 to 11 days later and checked daily, for 43 days, for the presence of vaginal plugs.

\section{RESULTS}

\section{Experiment 1}

As judged from the examination of uterine flushings, no leucocytes were present in the lumen of the uterus in intact mice. In mice in which IUDs had been left in situ, the leucocytes were present in all IUD-containing horns and in six of eight contralateral horns. When the IUD was removed on the 1st day of pregnancy, no leucocytes were seen on the 6th day in either horn. When the IUD was removed on the 4th day, the leucocytes were present in both horns 2 days later. Leucocytes were also observed in flushings from three out of ten mice from which an IUD had been removed on the 2nd or the 3rd day (Table 1). 
TABLE 1

PRESENGE OF LEUCOCYTES IN THE UTERINE FLUSHINGS AT DIFFERENT TIMES AFTER REMOVING THE IUD

\begin{tabular}{l|c|c|c|c|c}
\hline & & \multicolumn{2}{|c|}{ IUD horn } & \multicolumn{2}{c}{ Control horn } \\
\cline { 2 - 6 } Treatment & $\begin{array}{c}\text { No. of } \\
\text { animals }\end{array}$ & $\begin{array}{c}\text { No. of } \\
\text { horns with } \\
\text { implantations }\end{array}$ & $\begin{array}{c}\text { No. of } \\
\text { horns with } \\
\text { leucocytes* }\end{array}$ & $\begin{array}{c}\text { No. of } \\
\text { horns with } \\
\text { implantations }\end{array}$ & $\begin{array}{c}\text { No. of } \\
\text { horns with } \\
\text { leucocytes* }\end{array}$ \\
\hline Intact controls & 5 & - & - & 10 & 0 \\
IUD controls & 8 & 0 & 8 & 3 & 6 \\
IUD removed after & 4 & 4 & 0 & 4 & 0 \\
mating-1st day & 4 & 3 & 1 & 4 & 0 \\
$\quad$ 2nd day & 4 & 3 & 2 & 5 & 1 \\
3rd day & 6 & 0 & 2 & 1 & 2 \\
\hline
\end{tabular}

All animals were killed on the 6 th day of pregnancy.

* Flushings in which only few leucocytes were seen are not included.

Usually there were no visible implantations in the horns exhibiting definite leucocytosis.

\section{Experiment 2}

The leucocytic content of the uterus in intact and in IUD-bearing mice appeared independent of the interval from mating to killing and the results were, therefore, pooled. Two of seven untreated mice had a moderate number of leucocytes deep in the endometrial stroma, but in none was there any evidence of an accumulation of leucocytes under the endometrial epithelium or in the lumen. In all the IUD-bearing females, there was a massive infiltration of leucocytes in the IUD horn. Polymorphonuclear leucocytes were particularly

TABLE 2

PRESENCE OF LEUCOCYTES IN HISTOLOGICAL SECTIONS OF THE UTERUS AT DIFFERENT TIMES AFTER REMOVING THE IUD

\begin{tabular}{|c|c|c|c|c|c|c|c|}
\hline \multirow{3}{*}{ Treatment } & \multirow{3}{*}{$\begin{array}{c}\text { No. of } \\
\text { animals }\end{array}$} & \multicolumn{3}{|c|}{ IUD horn } & \multicolumn{3}{|c|}{ Control horn } \\
\hline & & \multirow{2}{*}{$\begin{array}{c}\text { No. of } \\
\text { horns } \\
\text { without } \\
\text { leucocytes }\end{array}$} & \multicolumn{2}{|c|}{$\begin{array}{l}\text { No. of horns with } \\
\text { leucocytes }\end{array}$} & \multirow{2}{*}{$\begin{array}{c}\text { No. of } \\
\text { horns } \\
\text { without } \\
\text { leucocytes* }\end{array}$} & \multicolumn{2}{|c|}{$\begin{array}{l}\text { No. of horns with } \\
\text { leucocytes }\end{array}$} \\
\hline & & & $\begin{array}{l}\text { Only in } \\
\text { endo- } \\
\text { metrium }\end{array}$ & $\begin{array}{c}\text { In lumen } \\
\text { and endo- } \\
\text { metrium }\end{array}$ & & $\begin{array}{l}\text { Only in } \\
\text { endo- } \\
\text { metrium }\end{array}$ & $\begin{array}{c}\text { In lumen } \\
\text { and endo- } \\
\text { metrium }\end{array}$ \\
\hline $\begin{array}{l}\text { Intact controls } \\
\text { IUD controls }\end{array}$ & ${ }_{8}^{7 \dagger}$ & $\overline{0}$ & $\overline{0}$ & $\overline{8}$ & $\begin{array}{l}5 \\
4\end{array}$ & $\begin{array}{l}2 \\
1\end{array}$ & $\begin{array}{l}0 \\
3\end{array}$ \\
\hline $\begin{array}{l}\text { killed-3rd day } \\
\text { 4th day } \\
\text { 5th day } \\
\text { 6th day }\end{array}$ & $\begin{array}{l}4 \\
3 \\
3 \\
3\end{array}$ & $\begin{array}{l}0 \\
2 \\
3 \\
3\end{array}$ & $\begin{array}{l}3 \\
1 \\
0 \\
0\end{array}$ & $\begin{array}{l}1 \\
0 \\
0 \\
0\end{array}$ & $\begin{array}{l}1 \\
3 \\
3 \\
3\end{array}$ & $\begin{array}{l}3 \\
0 \\
0 \\
0\end{array}$ & $\begin{array}{l}0 \\
0 \\
0 \\
0\end{array}$ \\
\hline
\end{tabular}

* This includes horns with isolated leucocytes seen in some of the sections and the horns of mice with implantations killed on 6 th day with some leucocytes in the lumen but none in the endometrium.

$\uparrow$ Only one horn was examined histologically. 
abundant in the lumen of the uterine segment containing the silk thread and in the endometrial stroma immediately beneath the epithelium. The contralateral horn was, with one exception, either heavily infiltrated or entirely free of leucocytes. Only one of the four animals killed 1 day after removing the IUD had leucocytes in the uterine lumen. Moreover, the number of leucocytes in the endometrium appeared to be reduced. In eight of the nine animals killed 2, 3 or 4 days after removing the IUD, there were no leucocytes in the endometrium or lumen (Table 2).

\section{Experiment 3}

In mice with IUDs, the mean duration of pseudopregnancy was slightly longer than in untreated control females; the difference was significant only in animals with unilateral IUDs. In hysterectomized mice, pseudopregnancy was significantly longer than in any of the remaining groups (Table 3 ). In both hysterectomized and IUD-bearing females, the mean pseudopregnancy length was significantly more variable than in intact controls $(P<0.01$ by $F$ test).

TABLE 3

DURATION OF PSEUDOPREGNANGY IN MICE WITH IUDS

\begin{tabular}{l|c|c|c|c}
\hline \multicolumn{1}{c|}{ Treatment } & $\begin{array}{c}\text { No. of } \\
\text { animals }\end{array}$ & $\begin{array}{c}\text { No. of } \\
\text { pseudopregnancies }\end{array}$ & $\begin{array}{c}\text { Length of pseudopregnancy } \\
\text { (days; mean } \pm \text { S.E.) }\end{array}$ & $\begin{array}{c}\text { Significance of the } \\
\text { difference from } \\
\text { intact controls }\end{array}$ \\
\hline Intact controls & 7 & 22 & $10 \cdot 3 \pm 0.15$ & -15 \\
Hysterectomized & 6 & 12 & $16.4 \pm 1.67$ & $<0.01^{*}$ \\
Unilateral IUD & 8 & 21 & $12.0 \pm 0.72$ & $<0.02$ \\
Bilateral IUD & 8 & 26 & $11.3 \pm 0.54$ & NS \\
\hline
\end{tabular}

* Pseudopregnancy in hysterectomized mice was also significantly longer than in mice with unilateral or bilateral IUDs $(P<0 \cdot 01)$.

\section{DISCUSSION}

The results of this study confirm the observations of Marston \& Kelly (1969) that in mice with unilateral IUDs the prevention of implantation is associated with the presence of large numbers of leucocytes in the uterine lumen and in the endometrium. The occurrence of pregnancy in untreated horns in a proportion of IUD-bearing females (Doyle \& Margolis, 1966, and the present study) agrees well with the observed absence of leucocytes in the untreated horn in some $50 \%$ of the animals studied. After the IUD was removed, the leucocytes disappeared very rapidly; in Exp. 2, they were usually not found in the uterine lumen $24 \mathrm{hr}$ later and within $48 \mathrm{hr}$, the endometrium also appeared free of leucocytes. In view of this, the finding of implantation 2 days after removing the IUD (Bartke, 1968) does not contradict the hypothesis that the IUD acts by causing uterine inflammation and leucocytic infiltration (Greenwald, 1965; Parr, Schaedler \& Hirsch, 1967). However, the apparent rate at which leucocytes completely disappear following the IUD removal seems to suggest that, at least in the present experiments, uterine leucocytosis was probably due to factors other than bacterial infection. 
Short-lasting invasion of the uterine lumen by polymorphonuclear leucocytes occurs after mating in mice (Austin, 1956) and in other rodents (Yanagimachi \& Chang, 1963). The leucocytes are most numerous some 12 to $14 \mathrm{hr}$ post coitum, but very few are found $24 \mathrm{hr}$ later. This may perhaps explain the more rapid rate of disappearance of leucocytes observed in Exp. 2 when IUDs were removed 1 day after mating, i.e. close to the time of natural decline in the number of leucocytes in the uterus.

The physiological significance of a slight prolongation of pseudopregnancy observed in mice with IUDs is not clear, but it seems to rule out the enhancement of the luteolytic action of the uterus as a mechanism for the anti-fertility effect of an IUD in this species. The duration of pseudopregnancy varied greatly, ranging from the normal length (9 to 11 days) to 20 days. This is reminiscent of a considerable individual variation observed in other effects of IUDs in mice and could perhaps be related to a different degree of luminal continuity between two uterine horns (Marston \& Kelly, 1969).

\section{ACKNOWLEDGMENTS}

This work was supported by the Ford Foundation through its Training Program in the Physiology of Reproduction. Conscientious help of Miss Joan Kosinsky, a summer student from the University of Massachusetts, was instrumental in completing this work and is gratefully acknowledged.

\section{REFERENGES}

Ausrin, C. R. (1956) Fate of spermatozoa in the uterus of the mouse and rat. F. Endocr. 14, 335.

BARTKE, A. (1968) Effect of an IUD on implantation and the decidual reaction in different strains of mice. J. Reprod. Fert. 15, 185.

Doyle, L. L. \& Margolrs, A. J. (1966) The effect of an IUFB on reproduction in mice. F. Reprod. Fert. 11, 27.

GreENWALD, G. S. (1965) Interruption of pregnancy in the rat by a uterine suture. F. Reprod. Fert. 9, 9.

Marston, J. H. \& Kelly, W. A. (1969) The time and site of contraceptive action of an intra-uterine device in the mouse. F. Endocr. 43, 83.

PARR, E. L. (1969a) Intrauterine foreign bodies: a toxic effect of leucocyte extracts on rat morulae in vitro. Biol. Reprod. $1,1$.

PARR, E. L. (1969b) The role of inflammation in the uterine weight increase caused by an IUD. F. Reprod. Fert. 18, 221.

ParR, E. L., Schaedler, R. W. \& Hirsch, J. G. (1967) The relationship of polymorphonuclear leucocytes to infertility in uteri containing foreign bodies. F. exp. Med. 126, 523.

YaNAGIMAGHI, R. \& GhaNG, M. C. (1963) Infiltration of leucocytes into the uterine lumen of the golden hamster during the oestrous cycle and following mating. F. Reprod. Fert. 5, 389. 